\title{
PREVALENCE OF HBV-GENOTYPES IN IMMIGRANTS AFFECTED BY HBV-RELATED CHRONIC ACTIVE HEPATITIS
}

\author{
Emilio PALUMBO, Gaetano SCOTTO, Giuseppina FALEO, Donatella Concetta CIBELLI, \\ Annalisa SARACINO and Gioacchino ANGARANO
}

\begin{abstract}
Background - The genetic heterogeneity of the HBV genome has been established and eight genotypes can be classified according to the criterion of $\geq 8 \%$ differences in the complete nucleotide sequence of the viral genome. Aims - To evaluate the prevalence of HBV-infection in a population of immigrants and to determine in patients with detectable serum HBV-DNA the HBV-genotypes. Methods - Between January 2005 and December 2005 a total of 556 immigrants were tested for HBsAg. In HBsAg positive patients the biochemical and virological activity of infection and the possible presence of co-infections (HCV, HDV, HIV) were evaluated. In patients with detectable serum HBV DNA, the HBVgenotype was determined by INNOLiPA. Results - Among the 556 subjects tested, 60 (10.7\%) resulted HBsAg positive. All were men, and 42 (70\%) come from Africa, 10 (16.6\%) from Asia and 9 (14.4\%) from East-Europe. 28/60 (46.6\%) patients presented normal ALT levels ( $<40$ IU/L) and undetectable serum HBV DNA ( $<100$ copies/mL in real-time PCR), while $32(53.4 \%)$ patients had ALT levels above laboratory normal values and detectable serum HBV DNA. Genotype distribution was as follow: genotype E, 16 (50\%), genotype D, 9 (28.1\%), genotype A, 7 (21.9\%). Conclusion - Our study evidences a moderate prevalence of HBV-infection in immigrants, particularly in sub-Saharan African people, and the potentiality of migratory flow in the introduction of genotype non-D hepatitis B virus, potentially characterized by a different natural history and, possibly, a different response to antiviral treatment.
\end{abstract}

HEADINGS - Genotype. Hepatitis B, chronic. Hepatitis B virus. Emigration and immigration. Italy.

\section{INTRODUCTION}

Hepatitis B virus (HBV) infection is a major health problem and more than 350 million of the world population are chronic carriers of the virus ${ }^{(2,11)}$. The genetic heterogeneity of the HBV genome has been established and eight genotypes (A to $\mathrm{H}$ ) can be classified, based on comparison of complete HBV genomes and in according to the criterion of $\geq 8 \%$ differences in the complete nucleotide sequence of the viral genome $^{(1,4,5,8,9,16,17,21)}$. HBV genotypes have a characteristic geographic distribution. Genotype A is widely distributed in Northwest Europe, North America and Central Africa, while genotypes $\mathrm{B}$ and $\mathrm{C}$ are present in Asia only; genotype $\mathrm{D}$ has been found worldwide with its highest prevalence in the Mediterranean $\operatorname{area}^{(16,21)}$ the Middle East and South Asia, particularly in India. Genotype E is found in sub-Saharan Africa and genotype $\mathrm{F}$ in South and Central America. Genotype $G$ has been found in France and in USA, but recent data point to a Central America or Mexican origin, while the newly discovered genotype $\mathrm{H}$, seems so far to be restricted to the northern part of Latin America ${ }^{(9)}$.
Some studies have recently suggested that the HBV genotype is correlated with the clinical features of HBV infection and with the response to antiviral treatments. In fact, with regard to genotypes $B$ and $C$, which are prevalent in Asia, genotype $\mathrm{C}$ has been shown to be more frequently found in severe liver disease and in hepatocellular carcinoma and it presents a lower response rate to interferon alfa therapy, while genotype B is associated with faster $\mathrm{HbeAg} /$ antiHBe seroconversion ${ }^{(4,5,6,8,18,20)}$. During treatment with lamivudine, YMDD variants seem to appear faster in genotype A patients than genotype D but appear earlier in genotype $\mathrm{D}^{(19)}$.

In Italy, where the prevalence of $\mathrm{HBV}$-infection is $2 \%$ $8 \%$, the prevalent genotype is $\mathrm{D}$ (in fact about $95 \%$ of Italian patients with HBV-infection presented this genotype $)^{(3)}$, but the migratory flow towards our country could be determine the introduction of genotype non-D HBV-infections.

The aim of this study was to evaluate the prevalence of HBV-infection in a population of immigrants and to determine in patients with detectable serum HBV-DNA the HBV-genotypes.

Clinic of Infectious Diseases, University of Foggia, Italy.

Correspondence: Dr. Emilio Palumbo - Clinic of Infectious Diseases, University of Foggia - Via Luigi Pinto 1-71000 - Foggia, Italy. E-mail: emipalu2003@yahoo it 


\section{METHODS}

Between January 2005 to December 2005 a total of 556 immigrants were tested for HBsAg. All subjects given written informed consent. Tested subjects were temporarily guests in a camp for refugees. They were in Italy by a mean period of 4 months (range 57 days -9 months) and the majority $(379,68.2 \%)$ come from Africa $(52 \%$ of all African subjects come from Eritrea, $22 \%$ from Liberia, 14\% from Sudan, 10 from Ethiopia and 2\% from Ghana). Ninety subjects (16.2\%) come from Asia (46\% from Pakistan, $38 \%$ from Bangladesh and 26\% from India), while 70 subjects (12.6\%) come from East-Europe (88\% from Albania, 10\% from Serbia and 2\% from Ukraine) and 17 (3\%) from South-America (13 subjects from Colombia and 4 from Peru). The mean age of all tested subjects was 22.6 years (range 15-47) and the major part were men $(474 / 556,85.2 \%)$.

In HBsAg positive patients the biochemical and virological activity of infection and the eventual presence of co-infections (HCV, HDV, HIV) were evaluated. In patients with detectable serum HBV DNA was determined the HBV-genotype.

HBsAg was assayed by commercial immunoassay (AbbottAuszyme Mc, Abbott Laboratories, North Chicago, IL, USA). Hepatitis B E Antigen (HbeAg) and antibody to HbeAg (anti$\mathrm{HBe}$ ) were detected by radioimmunoassay (HbeAg/antiHBe immunoradiometric DiaSorin, Vercelli, Italy). IgM and IgG antiHDV were tested with commercially available ELISA kits (Abbott Diagnostica, Weisbaden-Delkenheim, Germany). The presence of antibodies to HCV (anti-HCV) was determined with the use of a third-generation enzyme-linked immunoassorbent assay (HCV-ELISA, Ortho Diagnostic System, Raritan, NJ, USA) and confirmed by a third-generation recombinant immunoblot assay (RIBA, Ortho Diagnostic Systems, Raritan, NJ, USA). Antibodies to HIV (anti-HIV) were determined by EIA (HIV1/HIV2, Abbott) and positive results were confirmed by Western Blot. Serum HBV DNA levels were measured by a commercial PCR-real time with a detection limit of 100 copies $/ \mathrm{mL}$. Serum ALT was quantified by ultraviolet enzymatic assay (normal range 0-40 IU/L).

\section{Determination of HBV-genotypes}

Serum of all patients with detectable serum HBV DNA was stored to $-80^{\circ} \mathrm{C}$ then thawed to determine $\mathrm{HBV}$ genotype. For determination of HBV genotypes HBV DNA was extracted as described by STUYVER et al. ${ }^{(17)}$ The second step was the nucleic acid amplification of the HBV pol gene domain $\mathrm{B}$ and $\mathrm{C}$ by means of the polymerase chain reaction (PCR), for obtaining sequence information pertaining to codons 180 , 204 and 207 in the polymerase open reading frame. The extracted DNA was amplified over two rounds of PCR using biotinylated PCR primers. An exact copy of the template was producted after one cycle of denaturation, annealing and extension.

Because the amount of amplification product is generally not sufficient, a nested (second round) PCR was needed. After the two PCR for amplification, HBV-genotypes was determined by the INNO-LiPA HBV Genotyping (Innogenetics NV, Gent, Belgium). Biotinylated DNA material generated from the HBsAg open reading frame was hybridized with specific oligonucleotide probes immobilized as parallel lines on membrane-based strips. After hybridization, unhybridizated DNA was washed from the strip, and streptavidin labelled with alkaline phosphatase was added and bound to any biotinylated hybrid previously formed. Incubation with BCIP/NBT chromogen resulted in a purple/brown precipitate. The correct HBV genotype was determined by consulting an interpretation chart showing probe reactivity patterns for each HBV genotype.

\section{Statistical analysis}

A two-tailed Pearson $\mathrm{X}^{2}$ test was used to compare categorical data. Statistical significance was taken as $P<0.05$.

\section{RESULTS}

Among the 556 subjects tested, 60 (10.7\%) resulted HBsAg positive. All were men, with a mean age of 26 years (range 19-47) and $42(70 \%)$ come from Africa (15 from Liberia, 12 Sudan, 10 Eritrea and 5 Ethiopia), 10 (16.6\%) from Asia (5 from Pakistan and 5 from Bangladesh) and 8 (14.4\%) from East-Europe (all from Albania). All patients were anti-HBe positive, with IgM and IgG anti-HDV negative. No subject presented co-infection with HCV and HIV. Serum bilirubin, albumin and prothrombin time resulted normal in all subjects.

Twenty eight 28/60 (46.6\%) patients presented normal ALT levels $(<40 \mathrm{IU} / \mathrm{L})$ and undetectable serum HBV DNA $(<100 \mathrm{copies} / \mathrm{mL})$, while $32(53.4 \%)$ patients had ALT levels elevated above laboratory normal (mean level was $143 \mathrm{IU} / \mathrm{L}$, range 74-312) and serum HBV DNA detectable by PCR-Real Time (mean level 945.877 copies $/ \mathrm{mL}$, range 22.933-1.290.865).

Genotype distribution was finally determined in patients with detectable serum HBV DNA as follow: genotype E, 16 (50\%), genotype D, $9(28.1 \%)$, genotype A, $7(21.9 \%)$. No cases of mixed genotype were evidenced. All patients infected by genotype E come from sub-Saharan Africa ( 10 from Liberia and 6 from Sudan); the patients with genotype D come two from Eritrea, two from Sudan and five from Albania, while the patients infected by genotype A come from Eritrea (four subjects) and Ethiopia (three subjects).

The mean ALT levels and serum HBV DNA levels were similar among the three different genotype (150 IU/L and 954.650 copies/mL for genotype E vs $137 \mathrm{IU} / \mathrm{L}$ and 845.779 copies $/ \mathrm{mL}$ for genotype $\mathrm{D}$ vs $143 \mathrm{IU} / \mathrm{L}$ and 871.200 copies/mL for genotype A ) $(P=0.9$ for ALT and 0.7 for serum HBV) (Table 1).

TABLE 1. Distribution of HBV-genotypes in patients with detectable serum HBV-DNA and correlation between different genotypes with biochemical and virological activity of HBV-related disease

\begin{tabular}{ccccc}
\hline $\begin{array}{c}\text { HBV- } \\
\text { genotypes }\end{array}$ & $\begin{array}{c}\text { patients infected } \\
\text { by different } \\
\text { genotypes }\end{array}$ & Provenience & $\begin{array}{c}\text { Mean } \\
\text { ALT } \\
(\text { IU/L) }\end{array}$ & $\begin{array}{c}\text { Mean HBV } \\
\text { DNA } \\
\text { (copies/ml) }\end{array}$ \\
\hline E & $16(50 \%)$ & $\begin{array}{c}10 \text { Liberia } \\
6 \text { Sudan }\end{array}$ & 150 & 954650 \\
D & $9(28.1 \%)$ & $\begin{array}{c}2 \text { Eritrea } \\
\text { 5 Sudan }\end{array}$ & 137 & 845.779 \\
& $7(21.9 \%)$ & $\begin{array}{c}\text { Albania } \\
\text { 3 Eritrea }\end{array}$ & 143 & 871200 \\
A Ethiopia & & &
\end{tabular}

Statistical analysis not evidenced any significative correlation between biochemical and virological activity of the disease and the different HBV-genotypes 


\section{DISCUSSION}

Some recent studies have evidenced as in immigrants the prevalent infectious diseases are represented by HIV, tuberculosis and chronic viral hepatitis, more frequently caused by HBV, particularly in African people coming from sub-Saharan areas ${ }^{(7,12,13,15)}$. The principal aim of this study was to evaluate the prevalence of $\mathrm{HBV}$-infection in a population of immigrants, in Italy, by a mean period of 4 months. We have tested 556 subjects: the major part comes from sub-Saharan Africa and it reflects the actual prevalent migratory flow to Italy, prevalently characterized by people coming from Africa and, less frequently, from East-Europe. Among this population 60 subjects $(10.8 \%)$ resulted HBsAg positive and this rate was similar to similar observations presented in Italian and international literature ${ }^{(7,15)}$. No cases of co-infection were observed in this serie. Many of these subjects (about 50\%) presented normal ALT and undetectable serum HBV DNA in PCR. The data about the normal ALT levels is not surprising, because many studies have evidenced as, particularly in sub-Saharan African population, HBV-infection is characterized by an elevated prevalence $(>8 \%)$, but many infected subjects (a variable rate of $40 \%-65 \%$ in the different studies) not present biochemical activity of diseases ${ }^{(10,14,15)}$. The high rate of HBs-positive patients with undetectable DNA in PCR is probably connected with the use of primers not adequate for some HBV isolates from Africa. Our data evidenced the elevated prevalence of HBV-infection in immigrants, particularly in African subjects, connected principally with the absence of vaccine-prophylaxis and with at risk sexual behaviour. An important data concerned the sex of infected patients: all HBsAg positive subjects were men, but this data is probably expression of the difficulty in testing females (only 82/556 of tested subjects were females). In fact, in African communities females are afraid to know their eventual diseases, in particular infectious diseases that are considered an ulterior cause of social discrimination.

The second aim of the study was to determine, in patients with virological activity of infection (detectable serum HBV DNA), the prevalence of HBV-genotypes. In Italy, in the autochthon population affected by active chronic $\mathrm{B}$ hepatitis, HBV-genotypes are not investigated, because the major part of patients (about 95\%) presented genotype D; however, as demonstrated in this study, the migratory flow could determine the introduction in our country of patients infected by genotype non-D HBV.

Recently, there have been several studies reporting the influence of HBV genotypes on the clinical features and on the response to antiviral treatment (interferon and lamivudine) of patients infected with $\mathrm{HBV}^{(4,5,6,8,18,19,20)}$. Therefore these different genotypes, probably characterized by a different natural history and a different response to therapy, could require a different clinical and therapeutic approach as compared to genotype-D. In our study the prevalent genotype was E ( $50 \%$ of cases), evidenced exclusively in sub-Saharan patients. It coincides with the usual geographic distribution of this genotype, which is exclusively diffused in sub-Saharan areas. The seven patients affected by genotype A come from central Africa, where this genotype is effectively prevalent.

An indirect demonstration of the potential redistribution of HBV genotypes comes from the analysis of persons infected by genotype $\mathrm{D}$ in our series. In fact among the nine patients infected by genotype $\mathrm{D}$, five come from Albania, where this genotype is diffused, while four patients come from Central Africa, not usually characterized by the presence of this genotype. This could demonstrate as the global migratory flow in the world could determine a partial modification of the normal geographic distribution of HBV-genotype with the distribution of some genotype in areas where they are not precedently diffused. No case of genotype $\mathrm{B}$ and $\mathrm{C}$ was evidenced because the 10 Asiatic patients HBV-infected, presented undetectable serum HBV-DNA and, therefore, it was not possible to obtain an HBV-genotype. About the biochemical and virological activity of HBV-infection, while the mean ALT levels and HBV DNA serum levels were similar among the three different genotype.

In conclusion our study evidences a moderate prevalence of HBV-infection in immigrants, particularly in people from sub-Saharan Africa and underscore the potentiality of migratory flow in the introduction of genotype non-D hepatitis B virus, potentially characterized by different natural history and response to antiviral regimes that could require a different clinical and therapeutic approach as compared to D-genotype.

To investigate the clinical, virological and therapeutic response characteristics of HBV genotypes, further studies using a large number of samples, including those from patients with more severe liver diseases in various HBV endemic areas should be performed. 
Palumbo E, Scotto G, Faleo G, Cibelli DC, Saracino A, Angarano G. Prevalência dos genótipos do vírus da hepatite B em imigrantes na Itália com hepatite crônica ativa pelo vírus B. Arq Gastroenterol. 2007;44(1):54-7.

RESUMO - Racional - A heterogeneidade do genoma do vírus da hepatite B (VHB) foi estabelecida e oito genótipos podem ser classificados de acordo com o critério de diferenças de percentagem maior ou igual a 8 na seqüência completa do nucleotídeo do genoma vira!. Objetivos - Verificar a prevalência da infecção pelo vírus da hepatite B (VHB) em uma população de imigrantes na Itália e determinar os genótipos do VHB em pacientes com níveis séricos detectáveis do VHB-DNA. Métodos - Entre janeiro e dezembro de 2005, o total de 556 imigrantes foram testados para o HbsAg. Se positivos, a atividade bioquímica e viral da infecção e a possível presença de co-infecções (HVC, HVD e HIV) foram examinadas. Nos pacientes positivos para o VHB-DNA, o genótipo do VHB foi determinado pelo método INNOLiPA. Resultados - Entre os 556 pacientes, 60 (10,7\%) tinham HbsAg positivo. Todos eram do sexo masculino e 42 (70\%), provenientes da África, $10(16,6 \%)$ da Ásia e $9(14,4 \%)$ do Leste Europeu. 28/60 (46,6\%) apresentaram níveis de ALT normais (<40 UI/L) e soro negativo ou indetectável para o VHB-DNA ( $<100$ copies/mL PCR “real-time"), enquanto $32(53,4 \%)$ tinham níveis mais elevados de ALT e soro positivo para VHB-DNA. A distribuição do genótipo foi a seguinte: genótipo E, 16 (50\%), genótipo D, 9 (28,1\%), genótipo A, 7 (21,1\%). Conclusão - O estudo evidencia a prevalência moderada do HVB em imigrantes, particularmente na população africana, sub-Sahara e o potencial fluxo migratório na introdução da hepatite $\mathrm{B}$, genótipo não-D, potencialmente caracterizada pela história natural e possivelmente levar à diferença no tratamento anti-viral.

DESCRITORES - Genótipo. Hepatite B crônica. Vírus da hepatite B. Migração internacional. Itália

\section{REFERENCES}

1. Arauz-Ruiz P, Norder H, Robertson BH, Magnius LO. Genotype H: a new Ameridian genotype of hepatitis B virus revealed in Central America. J Gen Virol. $2002: 83: 2059-73$

2. Chu CM, Liau YF. Natural history of chronic B virus infection: an immunophatological study. J Gastroenterol Hepatol. 1997;12:s218-s22.

3. Fattovich G, Mcintyre G, Thursz M, Colman K, Giuliano G, Alberti A. Hepatitis B virus precore/core variation and interferon therapy. Hepatology. 1995;22:1355-62.

4. Hajime S, Osamu Y, Naohiko S, Makoto A, Fumio I, Tomoko K, Tatsuo K, Kenich F, Masaki K, Hiromitsu S. Influence of hepatitis B virus genotype on the progression of chronic type B liver disease. Hepatology. 2003;37:19-26.

5. Jia-Horng K, Nan-Hui W, Pei-Jer C, Ming-Yang L, Ding-Shinn C. Hepatitis B genotypes and the response to interferon therapy. J Hepatol. 2000;33:998-1002.

6. Lik-Yuen Chan H, Woon-Choi Tsang S, ChooK-Tiew L, Chi-Hang T, May-Ling W, Yuet-Ling Ching J, Wai-Yee Leung N, Siu-Lun Tam J, Jao-Yiu Sung J. Viral genotype and hepatitis B virus DNA levels are correlated with histological liver damage in $\mathrm{HbeAg}$ negative chronic hepatitis B virus infection. Am J Gastrenterol. 2002;97:406-12.

7. Lopez-Velez R, Huerga H, Turrientes MC. Infectious diseases in immigrants from the perspective of a tropical medicine referral unit. Am J Trop Med Hyg. 2003;69:115-21

8. Man-Fung Y, Erwin S, He-Jun Y, Danny Ka-Ho W, Chee-Kin H, Bewnjamin ChunYu W, Annie On-On C, Ching Lung L. Significance of hepatitis B genotype in acute exacerbation, HbeAg seroconversion, cirrhosis-related complications, and hepatocellula carcinoma. Hepatology. 2003;37:562-7.

9. Man-Fung Y, Erwin S, Yasuhito T, Takanobu K, Masashi M, Joke D, He-Jun Y, Danny Ka-Ho W, Siu-Man S, Ching-Lung L. Epidemiological study of hepatitis B virus genotypes, core promoter and precore mutations of chronic hepatitis B infection in Hong Kong. J Hepatol. 2004;41:119-25.

10. Paterson R. Screening immigrants for infectious diseases. Lancet Infect Dis. 2003;3:681.

11. Purcell RH. The discovery of the hepatitis viruses. Gastroenterology. 1993;104:955-63.
12. Ramos JM, Pastor C, Masia MFM, Cascales E, Royo G, Gutierrez-Rodero F. Health in the immigrant population: prevalence of latent tuberculosis, hepatitis B, hepatitis C, human immunodeficiency virus and syphilis infection. Enferm Infecc Microbiol Clin. 2003;21:540-2

13. Roberts A, Kemp C. Infectious diseases of refugees and immigrants: hookworm. J Am Acad Nurse Pract. 2002;14:194.

14. Schwanig M. Migration: public health issues (polio, hepatitis C, hepatitis B, tuberculosis, diphteria). Biologicals. 1997;25:187-93.

15. Scotto G, Saracino A, Pempinello R, El-Hamad I, Geraci S, Palumbo E, Cibelli DC, Angarano G, Grupo Italiano per lo Studio delle Malattie Infettive negli Immigranti. Epidemiological multicentric study on prevalence of hepatitis in hospitalised immigrants in Italy during 2002. Ann Ig. 2005;17:11-8.

16. Senturker Guldas N, Abacioglu YH. S-gene sequences and genotype-related restrinction sites in hepatitis B virus carriers in Turkey. Infection. 2004;32:344-9.

17. Stuyver L, De Gendt S, Van Geyt C, Zoulim F, Fried M, Schinazi RF, Rossau R. A new genotype of hepatitis virus: complete genome and phylogenetic relatedness. J Gen Virol. 2000;81:67-74.

18. Tsuboda A, Arase Y, Ren F, Tanaka H, Ikeda K, Kumada H. Genotype may correlate with liver carcinogenesis and tumor characteristics in cirrhotic patients infected with hepatitis B virus subtype adw. J Med Virol. 2001;65:257-65.

19. Valdes CA, Buti M, Costa X, Jardi R, Rodriguez F, Mesas I, Esteban R, Guardia J. The role of HBV genotype in the emergence of YMDD variants in chronic hepatitis $B$ patients treated with lamivudine [abstract]. J Hepatol. 2003;38(Suppl 2):abstr 613.

20. Xin D, Masashi M, Xianmin G, Etsuro O, Shiro I, Ryuzo U, Makoto N. Different hepatitis $\mathrm{B}$ virus genotype distribution among asymptomatic carriers and patients with liver diseases in Nanning, southern China. Hepatology Res. 2002;22:37-44.

21. Yalcin K, Degertekin H, Bahcecioglu IH, Demir A, Yildirim M, Horasanli S, Ciftci S, Badur S. Hepatitis B virus prevails in patients with persistently elevated or normal ALT levels in Turkey. Infection. 2004;32:24-9. 